\title{
Early trauma and mood disorders in youngsters
}

\author{
Trauma precoce e transtornos de humor em jovens
}

\author{
Caroline Elizabeth Konradt ${ }^{1}$, Karen Jansen ${ }^{1}$, Pedro Vieira da Silva Magalhães², Ricardo Tavares Pinheiro, \\ Flávio Pereira Kapczinski², Ricardo Azevedo da Silva ${ }^{1}$, Luciano Dias Mattos de Souza ${ }^{1}$
}

† Programa de Pós-Graduação em Saúde e Comportamento da Universidade Católica de Pelotas (UCPel), Pelotas, RS, Brasil.

2 Programa de Pós-Graduação em Ciências Médicas (Psiquiatria) da Universidade Federal do Rio Grande do Sul (UFRGS), Porto Alegre, RS, Brasil.

Received: 7/13/2012 - Accepted: 1/18/2013

\begin{abstract}
Objective: To verify early experiences of childhood abuse and neglect among young with bipolar disorder (BD), major depression (MDD), and controls. Method: Case-control study nested to a population-based cross-sectional study. The diagnosis was performed via the structured clinical interview for DSM-IV Axis I Disorders (SCID). Traumatic events were analyzed using the Portuguese version - Questionário sobre Traumas na Infância (CTQ) - based on the Childhood Trauma Questionnaire. Results: The sample comprised 231 adolescents with 95 individuals in the control group, 82 with MDD and 54 with BD ( 32 of type I and 22 type II). The prevalence of trauma or violence in childhood was $42.2 \%$; among those, $54.7 \%$ had $\mathrm{BD}, 62.2 \%$ had MDD and $18.1 \%$ were in the control group. Young people with BD or MDD obtained higher means in total CTQ and among their components when compared with those in the control group. Discussion: Reports on early traumatic experiences were more frequent among young people with mood disorders than in the general population, corroborating the literature on the subject. In this sense, the traumatic experiences during childhood seemed to contribute to the onset of the disorder.
\end{abstract}

Konradt CE, et al. / Rev Psiq Clín. 2013;40(3):93-6

Keywords: Early trauma, traumatic experience, mood disorders, bipolar disorder, major depression.

\section{Resumo}

Objetivo: Verificar vivências precoces de abuso e negligência na infância entre jovens com transtorno bipolar (TB), transtorno depressivo maior (TDM) e controles populacionais. Método: Estudo de caso-controle aninhado a um estudo transversal de base populacional. A confirmação do diagnóstico foi realizada por meio de entrevista clínica estruturada para transtornos de eixo I do DSM-IV (SCID) e os eventos traumáticos foram verificados pelo Questionário sobre traumas na infância (CTQ). Resultados: A amostra foi composta por 231 jovens, sendo 95 indivíduos no grupo controle, 82 com TDM e 54 com TB (32 do tipo I e 22 do tipo II). A prevalência de trauma na infância foi de $42,2 \%$, sendo $54,7 \%$ entre aqueles com TB, $62,2 \%$ entre os jovens com TDM e $18,1 \%$ entre o grupo controle. Os jovens com TB ou TDM apresentaram maiores médias no CTQ total e entre seus componentes quando comparados aos jovens do grupo controle, exceto o componente abuso sexual, em que se observou diferença estatística apenas entre o grupo controle e o grupo de jovens com transtorno bipolar. Conclusão: $O$ relato de vivências traumáticas precoces foi mais presente entre os jovens com transtornos de humor do que na população geral, confirmando o que a literatura traz sobre o tema. Nesse sentido, as vivências de trauma na infância parecem contribuir para o aparecimento dos transtornos de humor.

Konradt CE, et al. / Rev Psiq Clín. 2013;40(3):93-6

Palavras-chave: Trauma precoce, vivências traumáticas, transtornos de humor, transtorno bipolar, depressão maior.

\section{Introduction}

The term trauma comes from Greek and means wound, pierce ${ }^{1}$ and is being widely used in healthcare to identify the consequences of external violence ${ }^{2}$. Freud used the concept of trauma to the psychic plane, giving it the meaning of a violent shock that can break the protective barrier of the ego, which can cause lasting disruption on the psychic organization of the individual ${ }^{3}$. In this way, the trauma may refer to a single external event or an accumulation of them.

Lately there is a great interest in the relationship between early traumatic experiences and psychotic disorders primary ${ }^{4}$, particularly, when it comes to sexual or physical abuse ${ }^{5}$. Patients with a history of abuse often present a serious and complex psychopathology $y^{6,7}$.

There is a strong link between a history of childhood emotional abuse and diagnosis of depression in adulthood 8 , so as to $42 \%$ of the adults who have experienced early sexual abuse developed chronic depression 9 . There are a growing number of longitudinal studies relating childhood emotional abuse as development of symptoms and depressive episodes ${ }^{10}$.
Studies show that traumatic events in childhood are frequently reported by patients with bipolar disorder rather than by unipolar patients ${ }^{11,12}$. Evidences suggests that a traumatic experience during childhood not only predisposes the subject to bipolar disorder, as modulates the clinical expression of the disease, resulting in an earlier beginning of the same ${ }^{13}$.

It is noticed that is consensual in the literature, the relationship between childhood trauma, particularly sexual abuse, and diagnoses of mood disorders in adulthood. According to our results in this study, we can see that this type of trauma is most observed in TB than major depression and population controls. Thus, we emphasize the impact of sexual abuse on early diagnosis of bipolar disorder throughout the life.

Considering the consequences of a trauma experienced early can bring to the individual, it is important to pay attention to different traumatic experiences and what they can bring, especially when it comes to mood disorders. Therefore, the objective of this study is verify the early trauma experiences and mood disorders in youngsters. 


\section{Method}

This study is a case-control nested to a cross-sectional study of a population-based with young adults ${ }^{14}$. Briefly, the sample was constituted of 1,560 participants aged between 18-24 years living in the urban area of Pelotas, RS (Brazil). The sample selection was performed by conglomerates from August 2007 to December 2008, considering a population of 39,667 people in this age group according to current census of 448 sectors of the city ${ }^{15}$. In order to guarantee the inclusion of necessary sample, 89 census tracts were drawn systematically. After identifying the sample, subjects signed a consent form and completed a questionnaire that collected sociodemographic data, drug abuse, as well as a structured diagnostic interview. The study was approved by the Ethics Committee of UCPel 96/2006.

For the present study, we attempted to recruit all individuals from a population-based study which showed past or current manic episode (hypo) according to the diagnostic interview Mini International Neuropsychiatric Interview (MINI) based on DSM-IV criteria $^{16}$. Following this criteria, 93 young adults who had current or previous history of bipolar disorder and two groups of controls were recruited. The first was composed of people with no history of affective disorder who were randomly selected and matched for sex, age and economic status, according to the classification of the Brazilian Association of Research Companies (ABEP) ${ }^{17}$. Thus, this was a sample of population controls. He was also recruited a second control group, those subjects who had current depression but no history of mania or hypomania, this was a group of active controls.

In order to improve the reliability of the diagnosis, we performed a structured clinical interview for axis I disorders of the DSM-IV (Structured Clinical Interview for DSM-IV Disorders - SCID) ${ }^{18}$, used as a criteria definition of group to this study. The interviews were conducted by two psychologists, masters from PPG in Health and Behavior from Catholic University of Pelotas after training at the Hospital de Clínicas of Porto Alegre. The severity of depressive symptoms and manic symptoms were verified through the versions validated for the Brazilian population Hamilton Depression Rating Scale (HDRS) ${ }^{19}$ and Young Mania Rating Scale (YMRS) ${ }^{20}$.

Moreover, was used the Childhood Trauma Questionnaire (CTQ) ${ }^{21}$, in a version adapted for the Brazilian population by Grassi-Oliveira (2006). The questionnaire about childhood traumas is a self-administered inventory that assesses abuse or neglect during childhood. This instrument can be applied in adolescents (from 12 years) and in adults, it is composed of 28 items investigating five components traumatic: physical abuse, emotional abuse, sexual abuse, physical neglect and emotional neglect ${ }^{22}$.

After coding and double entry of data into the Epi-Info 6.04d, the instruments were recoded and analyzed using Stata 11. Initially, the socio-demographic and clinical characteristics of the sample were made between groups by chi-square and ANOVA tests. Following was processed syntax of CTQ to generate the component variables and total score.

The association between traumatic components and both groups was performed by chi-square test, while the total score of CTQ was presented as mean and standard deviation between the groups and the statistical differences were measured by ANOVA. In addition, we performed a linear regression model, adjusted for sex, age and education, in order to observe the association between the scores of the traumatic components and the total score of CTQ between diagnostic groups. For all hypothesis tests, associations were considered statistically significant when p-value $<0.05$.

\section{Results}

In total, 279 young people were matched, these 231 individuals $(83 \%$ of the original sample) participated in the reevaluation and $27 \%$ of young people were not located or refused to participate. Thus, after the confirmation of the diagnosis, the sample was distributed as follows: 95 subjects in the control group, 82 with MDD and 54 with BD (32 type I and 22 type II).
The table 1, presents information about socio-demographic and clinical characteristics of the sample according to diagnostic group. Thus, it can be seen that there is a higher prevalence of women among the diagnostic groups than in the control group $(\mathrm{p}=0,012)$ The age, economic status and educational level were similar between the diagnostic groups $(p>0,05)$.

In table 2, presents averages of the components of CTQ among the three groups in which young people with MDD or BD obtained similar means between the most components and statistically different from the control group, except for sexual abuse component that got only statistical difference between the control group and the group of young people with BD.

After the analysis adjusted for sex, age and education of the participants, all domains assessed by the scale of trauma were significantly associated with the presence of MDD and BD (Table 3).

The figure 1 shows the total scores of CTQ among the three groups, this shows that individuals with $\mathrm{BD}$ have the highest averages of traumatic events $(32,90 \pm 13,46)$ when compared to two control groups, depression $(29,70 \pm 10.01)$ and population control $(21,49$ $\pm 8,72$ ). However, there was no statistically significant difference between the two groups of mood disorders $(p=0,247)$.

Table 1. Socio-demographic and clinical characteristics of the sample according to diagnostic group

\begin{tabular}{|l|c|c|c|c|}
\hline & $\begin{array}{c}\text { Population } \\
\text { control } \\
(\mathrm{n}=95)\end{array}$ & $\begin{array}{c}\text { Major } \\
\text { depression } \\
(\mathrm{n}=82)\end{array}$ & $\begin{array}{c}\text { Bipolar } \\
\text { disorder } \\
(\mathrm{n}=54)\end{array}$ & P-value \\
\hline Age $^{*}$ & $22.4 \pm 2.2$ & $21.8 \pm 2.0$ & $21.8 \pm 2.2$ & 0.108 \\
\hline Female sex & $57.4(54)$ & $76.8(63)$ & $74.5(41)$ & 0.012 \\
\hline $\begin{array}{l}\text { Scholarity (years } \\
\text { of study) }\end{array}$ & $9.7 \pm 3.1$ & $8.8 \pm 2.7$ & $8.8 \pm 3.5$ & 0.173 \\
\hline $\begin{array}{l}\text { Socioeconomic } \\
\text { status (D or E) }\end{array}$ & $13.8(13)$ & $22.0(18)$ & $14.5(8)$ & 0.320 \\
\hline $\begin{array}{l}\text { Depressive } \\
\text { symptoms } \\
\text { (HDRS) }^{*}\end{array}$ & $1.55 \pm 3.4$ & $12.8 \pm 7.7$ & $14.6 \pm 8.6$ & 0.000 \\
\hline $\begin{array}{l}\text { Maniacs } \\
\text { symptoms } \\
\text { (YMRS) }\end{array}$ & $0.2 \pm 1.0$ & $0.5 \pm 1.7$ & $4.8 \pm 6.9$ & 0.000 \\
\hline $\begin{array}{l}\text { Previous } \\
\text { hospitalizations }\end{array}$ & $1.1(1)$ & $6.1(5)$ & $9.1(5)$ & 0.066 \\
\hline
\end{tabular}

${ }^{*}$ Average and standard deviation. ANOVA test.

${ }^{* *}$ Relative and absolute frequency. Chi-square test.

Table 2. Average and standard deviation of the questionnaire about trauma in childhood and its components (CTO)

\begin{tabular}{|l|c|c|c|c|}
\hline \multicolumn{1}{|c|}{ CT0 } & $\begin{array}{c}\text { Population } \\
\text { control }\end{array}$ & $\begin{array}{c}\text { Major } \\
\text { depression }\end{array}$ & $\begin{array}{c}\text { Bipolar } \\
\text { disorder }\end{array}$ & P-value \\
\hline $\begin{array}{l}\text { Physical } \\
\text { neglect }\end{array}$ & $4.80 \pm 1.81$ & $6.35 \pm 2.90$ & $6.01 \pm 3.22$ & 0.000 \\
\hline $\begin{array}{l}\text { Emotional } \\
\text { neglect* }\end{array}$ & $12.50 \pm 3.40$ & $14.3 \pm 4.54$ & $14.28 \pm 4.60$ & 0.005 \\
\hline $\begin{array}{l}\text { Sexual } \\
\text { abuse* }\end{array}$ & $0.32 \pm 1.90$ & $0.62 \pm 1.60$ & $1.56 \pm 3.87$ & 0.013 \\
\hline $\begin{array}{l}\text { Physical } \\
\text { abuse* }\end{array}$ & $1.21 \pm 2.35$ & $2.35 \pm 3.15$ & $3.55 \pm 4.88$ & 0.000 \\
\hline $\begin{array}{l}\text { Emotional } \\
\text { abuse }\end{array}$ & $2.63 \pm 3.40$ & $6.03 \pm 4.15$ & $7.53 \pm 5.53$ & 0.000 \\
\hline
\end{tabular}

* Significant difference by Bonferroni test between the control group and the group of young people with depression and bipolar disorder.

** Significant difference by Bonferroni test between the control group and the group of young people with bipolar disorder, but no difference between the control and depression. 
Table 3. Linear regression for variable of diagnostic group (control, major depression and bipolar disorder) adjusted for sex, age and education

\begin{tabular}{|l|c|c|}
\hline \multicolumn{1}{|c|}{ CT0 } & $\begin{array}{c}\text { Coefficient of the } \\
\text { regression (95\%Cl) }\end{array}$ & P-value \\
\hline Physical neglect & $0.75(0.24-1.25)$ & 0.004 \\
\hline Emotional neglect & $2.24(1.36-3.1)$ & 0.000 \\
\hline Sexual abuse & $0.61(0.15-1.08)$ & 0.009 \\
\hline Physical abuse & $1.06(0.43-1.70)$ & 0.001 \\
\hline Emotional abuse & $2.50(1.71-3.29)$ & 0.000 \\
\hline Total & $6.98(4.59-9.36)$ & 0.000 \\
\hline
\end{tabular}

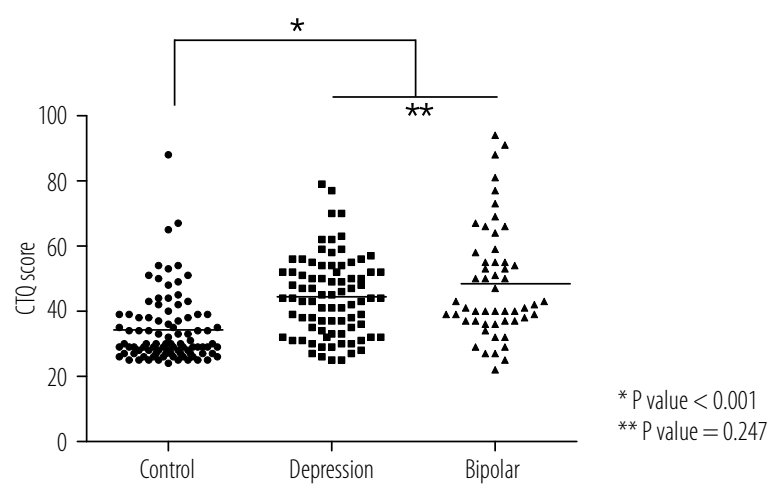

Figure 1. Childhood trauma scores among the three study groups.

\section{Discussion}

Lately it has been given great importance to the experience of early trauma, that because this issue is increasingly present in our daily lives and can bring heavy consequences throughout the life of the individual 7 . In this study, we can see that the story of early traumatic experiences occurs more frequently among young people with mood disorders than in the general population of young, confirming findings of literature 23,24 . However, was not confirmed difference between the score or the occurrence of traumatic events and the different mood disorders assessed, as found in literature ${ }^{11,13}$.

In this study the prevalence of individuals with mood disorders who reported no traumatic events (32\% MDD and $45 \% \mathrm{BD}$ ) was higher than that reported in a retrospective study of adults with severe mood disorders $(11 \%)^{25}$, possibly because of this study is about a population-representative sample of young people who the most part had not received a previous diagnosis, discrepant with the study cited that evaluated a convenience sample of adults in treatment with a mean age of 42 years.

The young people with mood disorders had higher scores on all components of CTQ, except in sexual abuse component that only the group with TB showed a statistical difference compared to the control group population, although recent studies indicate the relationship between childhood trauma and mood disorders in general ${ }^{26}$. In a systematic review, we found that childhood sexual abuse is not a specific risk factor for the development of depression, thus the traumatic experience can contribute to the early appearance of other disorders ${ }^{27}$. The findings of this study suggest that sexual abuse may be a specific risk factor for $\mathrm{BD}$.

Among youth with mood disorders, abuse and emotional neglect were the most prevalent components of CTQ, similar to a cohort study of 100 adults with BD in that emotional abuse was also the most reported type of trauma with a prevalence of $37 \%$, followed by physical abuse and emotional neglect ${ }^{14}$.

The findings in the literature associate the childhood trauma with a greater number of manic episodes ${ }^{28}$, more hospitalizations ${ }^{29}$, current symptoms of depressive mood ${ }^{30}$ early age of initiation ${ }^{31}$. In this study, because it is a sample in age of disease onset was not possible to verify variables that indicate worse clinical prognosis.
There are some limitations in the literature about the experiences of childhood trauma, this is because there are just a few instruments that assess trauma and even with some of those, there are people who believe that this is kind of intrusive questioning. The trauma during childhood is delicate to handle, even when addressed by a specific instrument as CTQ, it is known that the accounts of these experiences are influenced by memory bias, resulting in underestimation or overestimation of this exhibition. The other side, the findings related a correlation between the early beginning of mood disorders and the scores of $\mathrm{CTQ}^{30}$ as well as the lack of relationship between autobiographical memory and childhood trauma scores ${ }^{32}$.

It is important to note that were not excluded from this control group the subjects who had other mental disorders. In this sample were only evaluated diagnosis from axis I, which may have contributed to the no appearance of more serious disorders such as, for example, the personality, which could confound our results. One advantage of this study were the type of sample and the delineation, different from most studies with ambulatory design and convenience sampling, which the patients are already at an advanced stage of the disease. This indicates that even at the onset of the disorder, there is the story of early traumatic experiences and not just a pessimistic view of the past experiences of individuals with severe mood disorders.

To unleash the $\mathrm{BD}$ is necessary the occurrence of genetic and environmental factors, is not known the weight of each of these factors in the development of the disease, but the interaction. In this sense, the traumatic experiences occurring in childhood appear to contribute to the onset of the disorder. The childhood trauma has been considered a likely environmental risk factor for $\mathrm{BD}$, so it is a promising factor in future investigations that integrate environmental and genetic variables 23 .

It is not yet clear whether a specific type of trauma is more likely to induce specific psychiatric disorders ${ }^{31}$. Further studies should be conducted to increase the knowledge of the relationship between early traumatic experiences and mood disorders. Biological variables and clinical expression of mood disorders are factors that must be considered in relation to the presence of childhood trauma in population samples and longitudinal studies with early adolescents.

\section{References}

1. Ferreira $\mathrm{ABH}$. Novo dicionário Aurélio da língua portuguesa [revisado e ampliado]. 2a ed. Rio de Janeiro: Nova Fronteira; 1986.

2. Laplanche J, Pontalis JB. Vocabulário da psicanálise. $5^{\mathrm{a}}$ ed. Santos, SP: Martins Fontes; 1979.

3. Freud S. Moisés e o monoteísmo, 1939. In: Edição Standard Brasileira das Obras Psicológicas Completas de Sigmund Freud. Rio de Janeiro: Imago; 1976. p. 13-161.

4. Larkin W, Read J. Childhood trauma and psychosis: evidence, pathways, and implications. J Postgrad Med. 2008;54:287-93.

5. Teicher MH, Andersen SL, Polcari A, Anderson CM, Navalta CP, Kim DM. The neurobiological consequences of early stress and childhood maltreatment. Neurosci Biobehav Rev. 2003;27:33-44.

6. Lu W, Mueser KT, Rosenberg SD, Jankowski MK. Correlates of adverse childhood experiences among adults with severe mood disorders. Psychiatr Serv. 2008;59:1018-26.

7. Sanci L, Coffey C, Olsson C, Reid S, Carlin JB, Patton G. Childhood sexual abuse and eating disorders in females: findings from the Victorian Adolescent Health Cohort. Arch Pediatr Adolesc Med. 2008;162:261-7.

8. Bifulco A, Moran PM, Baines R, Bunn A, Stanford K. Exploring psychological abuse in childhood: II. Association with other abuse and adult clinical depression. Bull Menninger Clin. 2002;66:241-58.

9. Vitriol VG, Ballesteros ST, Florenzano RU, Weil KP, Benadof DF. Relationship between adult psychopathology and traumatic events in childhood [in Spanish]. Rev Chil Neuro-Psiquiatr. 2005;43:83-7.

10. Gibb BE, Alloy LB. A prospective test of the hopelessness theory of depression in children. J Clin Child Adolesc Psychol. 2006;35(2):264-74.

11. Maguire C, McCusker CG, Meenagh C, Mulholland C, Shannon C. Effects of trauma on bipolar disorder: the mediational role of interpersonal difficulties and alcohol dependence. Bipolar Disord. 2008;10:293-302. 
12. Savitz JB, van der Merwe L, Newman TK, Solms M, Stein DJ, Ramesar RS. The relationship between childhood abuse and dissociation. Is it influenced by catechol-O-methyltransferase (COMT) activity? Int J Neuropsychopharmacol. 2008;11:149-61.

13. Hyun M, Friedman SD, Dunner DL. Relationship of childhood physical and sexual abuse to adult bipolar disorder. Bipolar Disord. 2000;2:131-5.

14. Garno JL, Goldberg JF, Ramirez PM, Ritzler BA. Impact of childhood abuse on the clinical course of bipolar disorder. Br J Psychiatry. 2005;186:121-5.

15. Jansen K, Ores LD, Cardoso TD, Lima RD, Souza LD, Magalhães PV, et al. Prevalence of episodes of mania and hypomania and associated comorbidities among young adults. J Affect Disord. 2011;130:328-33.

16. Amorim P. Mini International Neuropsychiatric Interview (MINI): validação de entrevista breve para diagnóstico de transtornos mentais. Rev Bras Psiquiatr. 2000;22:106-15.

17. ABEP - Associação Brasileira de Empresas de Pesquisa, 2003. Dados com base no Levantamento Socioeconômico (IBOPE). Disponível em: $<$ http://www.ibge.gov.br>. Acesso em: maio 2008.

18. Del-Ben CM, Rodrigues CR, Zuardi AW. Reliability of the Portuguese version of the structured clinical interview for DSM-III-R (SCID) in a Brazilian sample of psychiatric outpatients. Braz J Med Biol Res. 1996;29:1675-82.

19. Fleck MP, Chaves ML, Poirier-Littre MF, Bourdel MC, Loo H, Guelfi JD. Depression in France and Brazil: factorial structure of the 17item Hamilton Depression Scale in inpatients. J Nerv Ment Dis. 2004;192:103-10.

20. Vilela JA, Crippa JA, Del-Ben CM, Loureiro SR. Reliability and validity of a Portuguese version of the Young Mania Rating Scale. Braz J Med Biol Res. 2005;38:1429-39.

21. Bernstein DP, Stein JA, Newcombc MD, Walker E, Pogge D, Ahluvalia $\mathrm{T}$, et al. Development and validation of a brief screening version of the Childhood Trauma Questionnaire. Child Abuse Negl. 2003;27:169-90.
22. Oliveira RG, Stein LM, Pezzi JC. Translation and content validation of the Childhood Trauma Questionnaire into Portuguese language. Rev Saude Publica. 2006:249-55.

23. Etain B, Henry C, Bellivier F, Mathieu F, Leboyer M. Beyond genetics: childhood affective trauma in bipolar disorder. Bipolar Disord. 2008; 10:867-76.

24. Etain B, Mathieu F, Henry C, Raust A, Roy I, Germain A, et al. Preferential association between childhood emotional abuse and bipolar disorder. J Trauma Stress. 2010;23:376-83.

25. Lu W, Mueser KT, Rosenberg SD, Jankowski MK. Correlates of adverse childhood experiences among adults with severe mood disorders. Psychiatr Serv. 2008;59:1018-26.

26. Alvarez MJ, Roura P, Osés A, Foguet Q, Solà J, Arrufat FX. Prevalence and clinical impact of childhood trauma in patients with severe mental disorders. J Nerv Ment Dis. 2011;3:156-61.

27. Maniglio R. Child sexual abuse in the etiology of depression: a systematic review of reviews. Depress Anxiety. 2010;27:631-42.

28. Garno JL, Goldberg JF, Ramirez PM, Ritzler BA. Impact of childhood abuse on the clinical course of bipolar illness. Br J Psychiatry. 2005;186:121-5.

29. Maguire C, McCusker C, Meenagh C, Mulholland C, Shannon C. The effects of trauma on bipolar disorder: the mediational role of interpersonal difficulties and alcohol dependence. Bipolar Disord. 2008;10:293-302.

30. Leboyer M, Etain B, Mathieu F, Henry C, Jamain S, Bellivier F. Childhood affective trauma in bipolar affective disorder. Bipolar Disord. 2007;9(1):9.

31. Goodman M, New A, Siever L. Trauma, genes, and the neurobiology of personality disorders. Ann N Y Acad Sci. 2004;1032:104-16.

32. Mowlds W, Shannon C, McCusker CG, Meenagh C, Robinson D, Wilson $A$, et al. Autobiographical memory specificity, depression and trauma in bipolar disorder. Br J Clin Psychol. 2010;49:217-33. 